GU J Sci, Part C, 5(1): 59-70 (2017)

Gazi Üniversitesi
Fen Bilimleri Dergisi
PART C: TASARIM VE TEKNOLOJI
dergipark.gov.tr/http-gujsc-gazi-edu-tr

\title{
Ultrasonik Ses Dalgası Ortamında Polielektrolit Varlığında Kalsiyum Karbonat Sentezi, Karakterizasyonu ve Deneysel Tasarım
}

\author{
Semra KIRBOĞA ${ }^{1, *}$ \\ ${ }^{I}$ Ylldız Teknik Üniversitesi, Kimya-Metalürji Fakültesi, Kimya Mühendisliği Bölümü, 34220, Esenler/ISTANBUL
}

$\ddot{O} \mathbf{z}$

Makale Bilgisi

Bașvuru: $26 / 08 / 2016$

Düzeltme: 22/12/2017

Kabul: 06/10/2017

Anahtar Kelimeler

Kalsiyum karbonat

Deneysel Tasarim

Ultrasonik ses dalgas

Polielektrolit

Keywords

Calcium carbonate

Experimental Design

Ultrasonic wave

Polyelectrolyte
Bu çalışmada ultrasonik ses dalgası (USD) uygulanarak suda çözünebilir polielektrolit olan polivinilsülfonik asit (PVS) varlığında kalsiyum karbonat $\left(\mathrm{CaCO}_{3}\right)$ sentezlenmiştir. Sentezlenen $\mathrm{CaCO}_{3}$ kristalleri X-ışınları kırınımı (XRD), taramaları elektron mikroskobu (SEM), Parçacık boyut dağılım analizi ve termogravimetrik analiz (TGA ve DTA) ile karakterize edilmiştir. $2^{\mathrm{k}}$ Faktöriyel Tasarım uygulanarak, sonikatör genliğinin, polimer konsantrasyonunun ve USD uygulama zamanının elde edilen kalsiyum karbonat kristallerinin boyutuna etkisi incelenmiştir. Deneysel tasarım iki seviyede gerçekleştirilmiştir. Seçilen tüm proses parametrelerinin PVS varlığında elde edilen kalsiyum karbonatın parçacık boyutunda çok etkili olduğu görülmüştür. Parametrelerin parçacık boyutuna etkisi polimer konsantrasyonu > USD uygulama zamanı > sonikatör genliği şeklinde olduğu görülmüş̧ür.

\section{The Synthesis and Characterization of Calcium Carbonate in the Presence of Polyelectrolyte and Experimental Design}

\begin{abstract}
In this study, calcium carbonate $\left(\mathrm{CaCO}_{3}\right)$ was synthesized by means of ultrasonic irradiation process in the presence of the water-soluble polyelectrolyte Poly(Vinyl Sulfonic Acid) (PVS). Synthesized $\mathrm{CaCO}_{3}$ crystals were characterized by X-ray diffraction (XRD), scanning electron microscopy (SEM), Particle size distribution analysis and thermal analysis (TGA-DTA). The effects of the amplitude of sonicator, polymer concentration and the application time of ultrasound on the obtained $\mathrm{CaCO}_{3}$ with respect to particle size of final product was investigated by applying the $2^{\mathrm{k}}$ Factorial Design. The experimental design was studied at two levels. All the selected process parameters were found to be very effective on the particle size of calcium carbonate obtained in the presence of PVS. The order of factor strength on particle size was polymer concentration $>$ the application time of ultrasound $>$ the amplitude of sonicator.
\end{abstract}

\section{GİRIŞ (INTRODUCTION)}

Kalsiyum karbonat $\left(\mathrm{CaCO}_{3}\right)$, doğadaki zenginliği ve laboratuvar çalıșmaları için çekici bir mineral olması nedeni ile son yıllarda araştırmacıların büyük ilgisini çekmektedir. Kalsiyum karbonat dolgu maddesi olarak boya, kağıt, kauçuk, plastik, seramik, ilaç, tekstil, gıda, kataliz vb. endüstriyel alanlarda kullanılmaktadır. Bunun dışında kalsiyum karbonat $\left(\mathrm{CaCO}_{3}\right)$ çevredeki ağır metaller ile güçlü etkileşimi, endüstriyel su arıtımı ve enerji depolanması gibi alanlarda kullanılması nedeniyle önemli minerallerden biridir. İyi bir biyolojik uyum ve uygun biyolojik bozunma hızına sahip olan kalsiyum karbonat, kemik ve diş gibi biyomedikal alanlarda kullanılabilir [1-5]. İnorganik malzemelerin belirli morfolojide, belirli parçacık boyutunda ve polimorfta olması endüstri için çok önemlidir. Malzemedeki spesifik özellikler pek çok alanda yeni malzemelerin yada cihazların tasarımında önemli rol oynamaktadır. İnorganik malzemelerin çekirdeklenmesi ve büyümesini kontrol etmek için proses parametrelerinin anlaşılması önemli bir faktördür. Kristalizasyonu kontrol eden parametrelerden bazıları reaktant konsantrasyonu, sıcaklık, iyonik güç, ortamın pH'1, katkı maddesinin yapısıdır [1-6]. 
Kalsiyum karbonat sistemlerindeki büyük ilgi kalsiyum karbonatın polimorflarından kaynaklanmaktadır. Kalsiyum karbonat polimorfları kalsit, aragonit, vaterit olarak bilinmektedir. Kalsit, $\mathrm{CaCO}_{3}$ 'ün en kararlı yapısıdır ve oda koşullarında atmosferik basınçta oluşmaktadır. Vaterit ise doğal olarak çok nadir bulunan bir mineraldir. Vaterit düşük spesifik gravitesinden dolayı dolgu maddesi olarak plastik ve kağıt endüstrisi gibi birçok uygulamada daha yüksek performans göstermektedir. Düşük spesifik gravite aynı ağırlık miktarı için yüksek hacim olană̆1 sağlamaktadır. Lüminesans özelliği ve kırılma indeksinin daha iyi olmasından dolayı vateritin kullanımı ile yüksek kalitede kağıt üretilebilir [1-4].

Kalsiyum karbonatın sentez koşulları kristalin şekli, boyutu ve morfolojisini etkilemektedir. Çöktürme kinetiğini arttırmak için sisteme harici bir enerji vermek tercih edilen bir yöntemdir. Ultrasonik ses dalgaları bu amaçla kullanılabilecek iyi bir harici enerji kaynağı olarak görülmektedir. Son yıllarda kristal boyutunda avantaj elde etmek için ultrasonik ses dalgası kullanılmaktadır [7]. Ultrasonik ses dalgası (USD), reaksiyonu hızlandırmak için özel şartlar sunmaktadır. Bu şekilde geleneksel metotlarla elde edilmesi mümkün olmayan kristal boyutlar elde edilebilmektedir [8]. Ultrasonik ses dalgası genellikle kristalizasyonda, hızlı birincil çekirdeklenme, kolay çekirdeklenme, ikincil çekirdeklenmenin başlaması ve tek düze yapıda daha küçük kristaller elde edilmesinde etkilidir. Ultrasonik ses dalgası uygulaması kalsiyum karbonat üretimi için gelecek vaat eden ve çevreye zararsız bir yöntemdir [9-15].

Bu çalışmada, deneysel parametrelerinin kalsiyum karbonat kristalizasyonu üzerine etkisi incelenmiştir. Sonikatör genliği, polimer konsantrasyonu ve ultrasonik ses dalgası uygulama zamanı proses parametreleri olarak seçilmiştir. Suda çözünen polimer olarak polivinilsülfonik asit kullanılmıştır. Sülfonik asit gruplarının çevreye herhangi bir zararının olmadığı, sağlık konusunda yapılan çalışmalarla desteklenmektedir. Organik polimer ve sülfonik grup içeren organik-inorganik yapıların kemiklerin yenilenmesinde çalışıldığ 1 literatürde mevcuttur [16]. USD uygulanarak polimer varlığında elde edilen kristaller XRD, SEM, TGA-DTA ve parçacık boyut dağılım analizi ile karakterize edilmiştir. Proses parametrelerinin kristal parçacık boyutuna etkisini belirlemek için $2^{\mathrm{k}}$ Faktöriyel tasarım uygulanmıştır. $\mathrm{Bu}$ deneysel tasarım sayesinde, belirlenen deneysel koşullar altında proses parametrelerinin ayrı ayrı etkisinin yanı sıra birbirleriyle etkileşimleri de araştırılmıştır.

\section{MATERYAL VE METOD (MATERIALS AND METHODS)}

\subsection{Kalsiyum Karbonat Kristalizasyonu}

Kalsiyum karbonat kristalizasyon deneylerinde sodyum karbonat $\left(\mathrm{Na}_{2} \mathrm{CO}_{3} \mathrm{Merck}\right)$, kalsiyum klorür dihidrat $\left(\mathrm{CaCl}_{2} \cdot 2 \mathrm{H}_{2} \mathrm{O}\right.$ Merck) ve Polivinilsülfonik asit (Aldrich) kullanılmıştır. USD etkisinin incelendiği deneyler $500 \mathrm{~mL}$ hacimli çift cidarlı reaktörde $25^{\circ} \mathrm{C}$ sıcaklıkta gerçekleştirilmiştir. Deneylerde $100 \mathrm{mM}$ $\mathrm{Na}_{2} \mathrm{CO}_{3}$ ve $\mathrm{CaCl}_{2} \cdot 2 \mathrm{H}_{2} \mathrm{O}$ stok çözeltileri kullanılmıştır. Reaksiyon eşit hacimdeki stok çözeltilerinin hızlıca karıştırılması ile gerçekleştirilmiştir. PVS polimeri, $\mathrm{Na}_{2} \mathrm{CO}_{3}$ çözeltisi ile birlikte reaktöre ilave edilmiştir. USD etkisinin incelendiği deneyler Extender $1 / 2$ Dia Full Wave model $13 \mathrm{~mm}$ çapında ve $254 \mathrm{~mm}$ uzunluğunda ucu burgulu değiştirilebilir tipte probu olan Sonikatör (Sonics Vibra Cell) kullanılarak 1 ve 5 dakika sürmüştür. Kullanılan prob 10-250 mL çözeltiler için uygun olan yüksek yoğunlukta ses dalgasında çalışabilen standart probtur. Sonikatör genlik değeri $\% 25$ ve $\% 50$ olarak uygulanırken, polimer konsantrasyonu $0.25 \mathrm{~g} / \mathrm{L}$ ve $0.75 \mathrm{~g} / \mathrm{L}$ olarak seçilmiştir. Elde edilen kalsiyum karbonat kristalleri $0.2 \mu \mathrm{m}$ selüloz nitrat membran ile vakum altında süzülmüş ve $100^{\circ} \mathrm{C}$ 'de etüvde 24 saat kurutulmuştur. Deneyler en az üç kez tekrarlanıp ortalama değer alınmıştır. Deneysel koşullar uygulanan deneysel tasarıma göre belirlenmiştir.

Polimer (PVS) varlığında elde edilen kalsiyum karbonat kristalleri XRD, Elektron Tarama Mikroskobu (SEM), Termogravimetrik (TG/DTA) analiz ve parçacık boyut dağılım analizi ile karakterize edilmiştir. XRD analizi PHILIPS PANalyticalX'Pert Pro PW 3040/60 model XRD cihazında gerçekleştirilmiştir. Anot malzemesi Cu olan (1.54060 A dalga boyu) XRD cihazında $45 \mathrm{kV}$ ve 40 mA'de çalışılmıştır. 5- 90 ${ }^{\circ} \mathrm{C}$ arasında değişen difraksiyon açılarında $0.026^{\circ}$ aralıklarda ölçüm alınmıştır. SEM analizleri FEIPhilips XL 30 ESEM-FEG model cihaz ile gerçekleştirilmiştir. Perkin Elmer Diamond TG/DTA Thermogravimetric Differential Thermal Analyzer cihazı kullanılarak numunelerin termogravimetrik analizleri yapılmıştır. Numuneler oksijen atmosferinde $10{ }^{\circ} \mathrm{C} / \mathrm{dk}$ ssıtma hızı kullanılarak, $800{ }^{\circ} \mathrm{C}$ 'ye 
1sıtılarak termogravimetrik analize tabi tutulmuştur. Parçacık boyut dağılım analizi 0.3-300 $\mu \mathrm{m}$ arasında ölçüm yapmaya olanak veren Fritsch Analysette 22-Compact cihazı ile yapılmıştır.

\subsection{Deneysel Tasarım}

Parametrelerin etkileri tek değişkenli olarak incelenmesinin yanı sıra parametrelerin aynı anda değiştirilmesi ile meydana gelecek değişiklikleri belirlemek için deneysel tasarım yöntemi uygulanmaktadır. Deneysel tasarım çerçevesinde yapılan deneylerden elde edilen sonuçlar ile model denklemin oluşturulması için polinom model kullanılmaktadır. Bu polinom, cevabının parametre değerlerinin aynı anda değiştirilmesinden nasıl etkilendiğini göstermektedir. $2^{\mathrm{k}}$ Faktöriyel Tasarımlarda genellikle kullanılan model Eşitlik (2.1) ile verilmiştir [1].

$$
\mathrm{Y}=\beta_{0}+\sum_{i=1}^{k} \beta_{i} x_{i}+\sum_{i=1}^{k} \sum_{j>1}^{k} \beta_{i j} x_{i} x_{j}+\sum_{i=1}^{k} \sum_{j>1}^{k} \sum_{k>1}^{k} \beta_{i j k} x_{i} x_{j} x_{k}
$$

Burada Y, sistemin cevabı, $\beta_{0}$ sabit, $\beta_{\mathrm{i}}, \beta_{\mathrm{ij}}$, $\beta_{\mathrm{ijk}}$ her bir faktörün katsayıs1, $\mathrm{x}_{\mathrm{i}}, \mathrm{x}_{\mathrm{j}}, \mathrm{x}_{\mathrm{k}}$ ise kodlanmış değişkenler, $\mathrm{k}$ ise faktör sayısıdır.

Oluşturulacak model denklikteki katsayıların hesaplanması amacıyla regresyon analizi yapılmaktadır. Deneylerde elde edilen sonuçlar ile model denklem olarak elde edilen polinom arasındaki uygunluk derecesini anlayabilmek için kalanların toplamına ve korelasyon katsayılarına bakılmaktadır. Kalanların toplamının "0", korelasyon katsayısının (R) ise "1"'e yakın olması deneysel veriler ile model denklikten elde edilen verilerin yakınlık derecesini göstermektedir.

Elde edilen model denklem, istatistiksel anlam açısından uygunluğunun test edilmesi amacıyla, varyans analizi (ANOVA) ile incelenmektedir. ANOVA, önerilen model denklemin deneysel değerleri temsil etmedeki etkinliğini gösteren bir tekniktir [17]. Varyans analizi oluş̧turulurken anlamlılık düzeyi (önem seviyesi) seçilmektedir. En çok kullanılan önem seviyesi \%95'tir. Seçilen bu önem seviyesi, önerilen model denkliğin \%5 olasılıkla reddedilebileceğini başka bir ifade ile model denklemin uygunluk kararının $\% 95$ güvenle verilmiş olmasından emin olunabileceğini ifade etmektedir. Varyans analizindeki F tabloları belirlenen önem seviyesinde model ve kalanların serbestlik dereceleri göz önüne alınarak oluşturulmaktadır. ANOVA çizelgesinde $\mathrm{F}$ testi yerine $p$ değeri ile de model denkliğin uygunluğu değerlendirilebilmektedir [17].

\section{SONUÇ VE TARTIŞMA (RESULT AND DISCUSSION)}

\subsection{XRD Analiz Sonuçları}

Deneysel koşullarda elde edilen kalsiyum karbonat kristalleri Tablo 1'de verilmiştir. Farklı deneysel koşullar hakkında bilgi veren örnek kodlama sistemi kullanılmıştır. Kodlamada harfin solunda yer alan sayı kullanılan polimer konsantrasyonunu (g/L), harfin sağındaki sayı sonikatör genliğini (\%) ve kısa çizgiden sonraki sayı ise ultrasonik ses dalgası uygulama zamanını (dk) göstermektedir. Örnek, 0.25B501 şeklinde kodlanan numune $0.25 \mathrm{~g} / \mathrm{L}$ PVS varlığında, \%50 sonikatör genliğinde 1 dakika boyunca ultrasonik ses dalgası uygulandığında elde edilen numuneyi göstermektedir.

Tablo 1. Kalsiyum karbonat kristalizasyonu deneysel koşulları

\begin{tabular}{cccl|ccrc}
\hline $\begin{array}{c}{[\mathrm{PVS}]} \\
(\mathrm{g} / \mathrm{L})\end{array}$ & $\begin{array}{c}\text { Genlik } \\
\%\end{array}$ & $\begin{array}{c}\text { Zaman } \\
(\mathrm{dk})\end{array}$ & $\begin{array}{l}\text { Örnek } \\
\text { kodlama }\end{array}$ & $\begin{array}{c}\text { [PVS }] \\
(\mathrm{g} / \mathrm{L})\end{array}$ & $\begin{array}{c}\text { Genlik } \\
\%\end{array}$ & $\begin{array}{c}\text { Zaman } \\
(\mathrm{dk})\end{array}$ & $\begin{array}{l}\text { Örnek } \\
\text { kodlama }\end{array}$ \\
\hline 0.25 & 25 & 1 & $0.25 \mathrm{~B} 25-1$ & 0.25 & 25 & 5 & $0.25 \mathrm{~B} 25-5$ \\
0.25 & 50 & 1 & $0.25 \mathrm{~B} 50-1$ & 0.25 & 50 & 5 & $0.25 \mathrm{~B} 50-5$ \\
0.75 & 25 & 1 & $0.75 \mathrm{~B} 25-1$ & 0.75 & 25 & 5 & $0.75 \mathrm{~B} 25-5$ \\
0.75 & 50 & 1 & $0.75 \mathrm{~B} 50-1$ & 0.75 & 50 & 5 & $0.75 \mathrm{~B} 50-5$ \\
\hline
\end{tabular}


Polimer varlığında sentezlenen kristaller XRD kullanılarak karakterize edilmiştir. XRD analizine göre $2 \theta$ tarama açısı olan $29.4^{\circ}, 35.9^{\circ}$ ve $39.5^{\circ}$ tarama açıları kalsit polimorfunun karakteristik pikleridir [2-4, 18-23]. Vateritin karakteristik pikini temsil eden tarama açıları ise $24.9^{\circ}, 26.9^{\circ}$ ve $32.7^{\circ}$, dir $[2-4,24$, 25].Şekil 1'de kalsiyum karbonat kristallerinin XRD spektrumu yer almaktadır. Polimer yokluğunda (Şekil 1a) ultrasonik ses dalgası uygulandığında saf kalsit elde edilmiştir [4]. PVS ilavesi ile vaterit polimorfu elde edilmiştir (Şekil 1b).
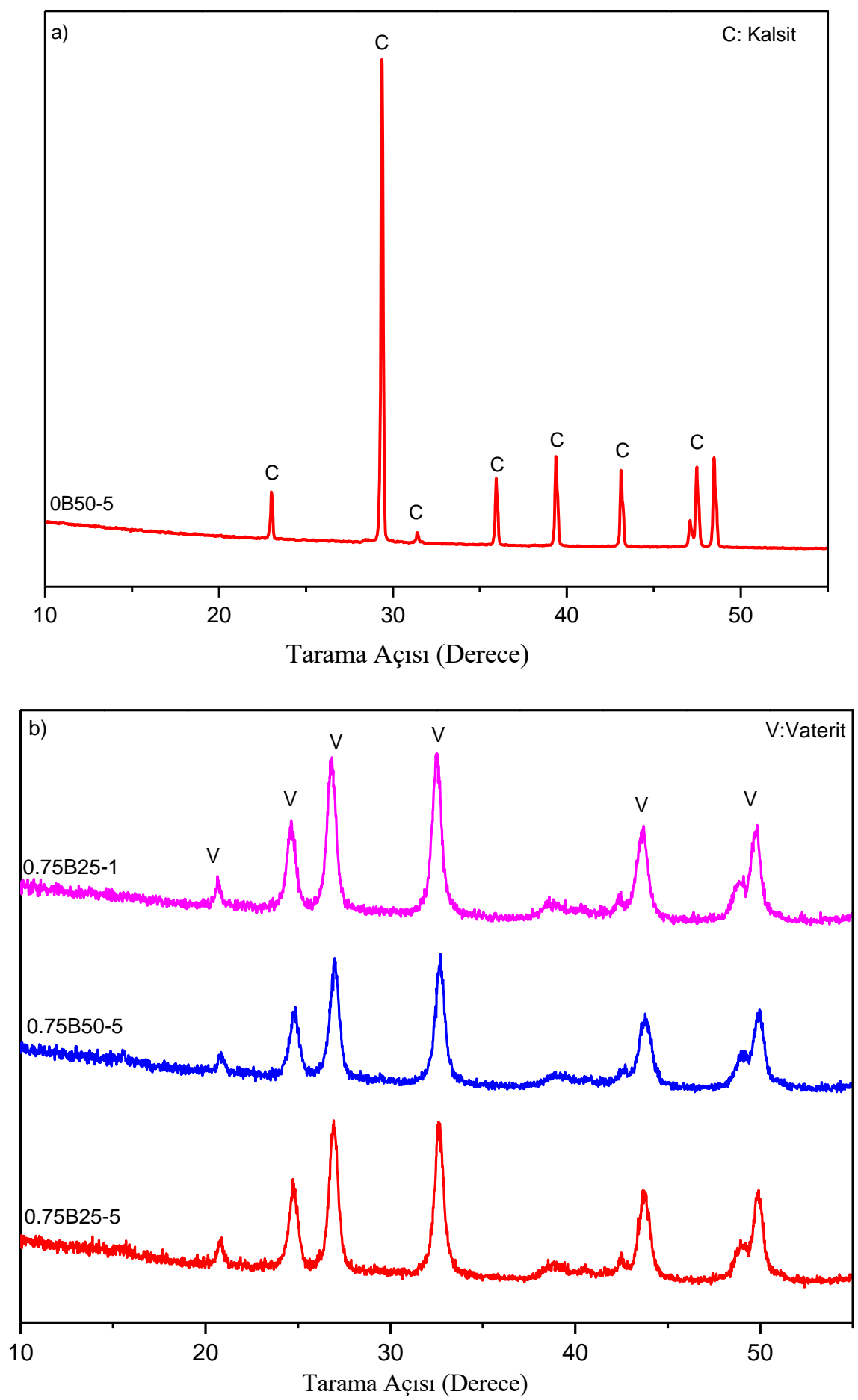

Şekil 1. PVS varlı̆ğnda ve yokluğunda elde edilen $\mathrm{CaCO}_{3}$ kristalinin XRD sonucu 
Katkı maddesi olarak kullanmış olduğumuz PVS'in kalsiyum karbonat polimorf yapısını değiştirdiği XRD ile kanıtlanmıştır. PVS'in yapısındaki negatif yüklü sülfonat grupları çekirdeklenme hızını düşürerek vateritin kalsite dönüşümünü engellemiştir. Kalsiyum karbonatın yüzey yük yoğunluğu polimer ilavesi ile düşmektedir ve parçacıklar arasındaki elektrostatik itmeler parçacıkların bir araya gelmesini engellemektedir. Bu yüksek yüzey yük yoğunluğu sayesinde vaterit kararlı halde kalmıştır [26].

\subsection{SEM ve Parçacık Boyut Dağılım Analiz Sonuçları}

Katk1 maddesi olarak kullanılan PVS polimerinin kalsiyum karbonat morfolojisinine etkisini incelemek için numunelerin SEM fotoğrafları çekilmiştir. PVS varlığında elde edilen $\mathrm{CaCO}_{3}$ kristallerinin SEM görüntüsü Şekil 2'de verilmiştir. Polimer yokluğunda USD ortamında yapılan önceki çalışmalarımızda [4] karakteristik rombohedral kalsit elde edilmiştir. Bu çalışmada ise PVS varlığında küresel vaterit elde edilmiştir (Şekil 2). Numunelere ait SEM görüntüleri XRD analizini desteklemektedir.

Elde edilen kristallerin parçacık boyut dağılımı ölçümü Fritsch Analysette 22 Compact cihazı ile yapılmıştır. Fritsch Analysette 22 Compact cihazı numunedeki bileşenlerin boyut dağılımındaki ufak değişiklikleri tespit edebilen bir ölçüm cihazıdır [27]. Parçacık boyutunun nasıl değiştiğini anlamak için farklı polimer konsantrasyonu, sonikatör genliği ve USD uygulama zamanı kullanılmıştır.

Elde edilen kalsiyum karbonat kristalleri için sayısal boyut dağılımı Şekil 3'te verilmiştir. Şekil 3'te görüleceği üzere, parçacık boyutunu en çok etkileyen parametreler polimer konsantrasyonu ve USD uygulama zamanıdır. Katkı maddesi olarak ilave edilen PVS miktarı arttıkça kristallerin boyutu azalmıştır. Benzer şekilde, USD uygulama zamanı 1 dakikadan 5 dakikaya çıktığında elde edilen kristallerin boyutu oldukça küçülmüştür. Sonikatör genliği de benzer fakat diğer parametreler ile karşılaştırıldığında daha az etki göstermektedir. \%25 sonikatör genlik değerinde 5 dakika USD uygulandığında polimer konsantrasyonu $0.25 \mathrm{~g} / \mathrm{L}$ iken (0.25B05-5 numunesi) elde edilen kristallerin d50 değeri $1.415 \mu \mathrm{m}$ iken, polimer konsantrasyonu $0.75 \mathrm{~g} / \mathrm{L}$ 'ye çıktığında $(0.75 \mathrm{~B} 25-5$ numunesi) parçacık boyutu $1.267 \mu$ m'ye düşmüştür. Minimum parçacık boyutu deneysel parametrelerin maksimum değerinde elde edilmiştir. Deneylerden elde edilen d50 değeri Tablo 2'de verilmiştir.
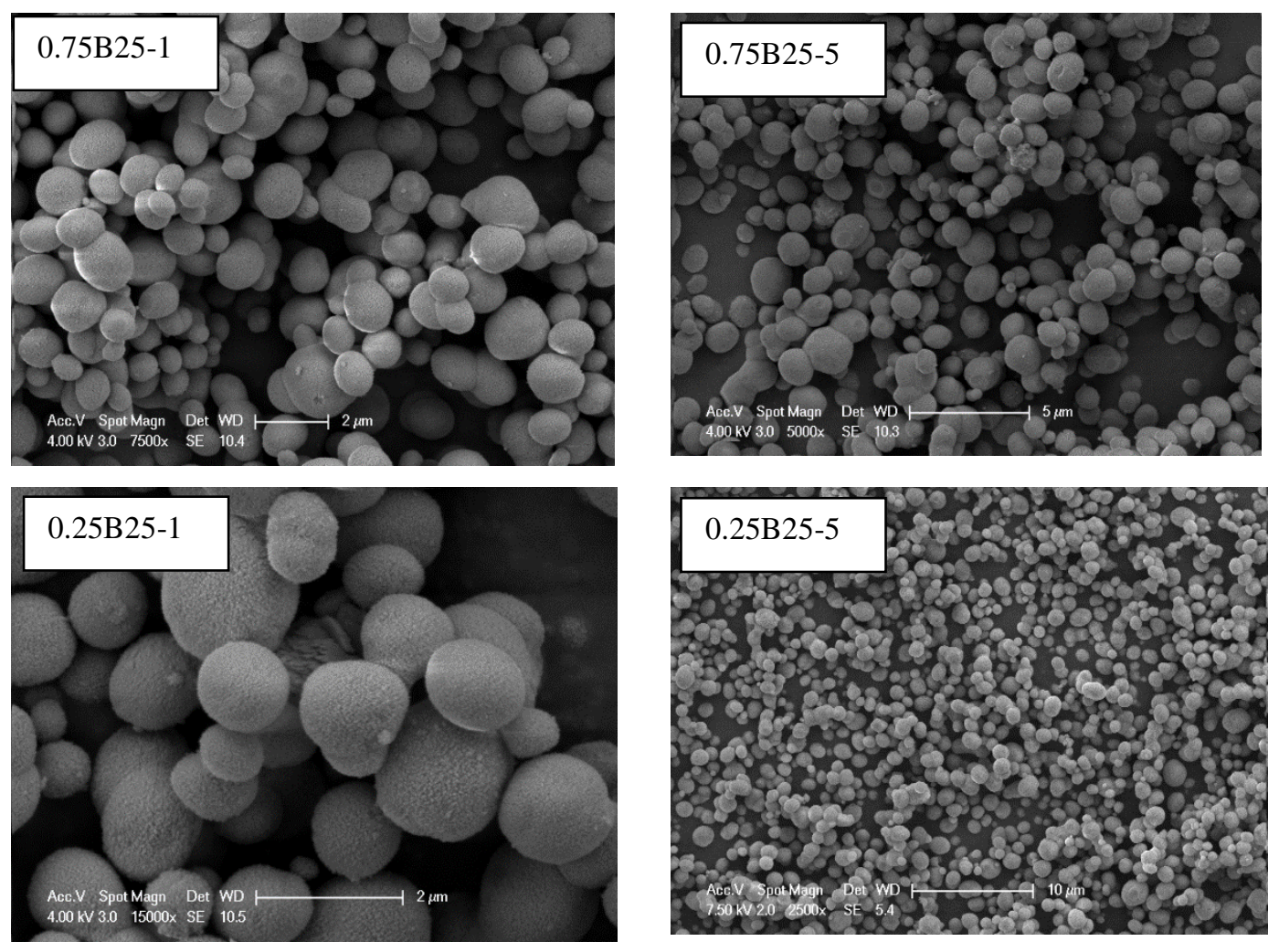

Şekil 2. $P V S$ varlığında elde edilen $\mathrm{CaCO}_{3}$ kristalinin SEM görüntüsü 


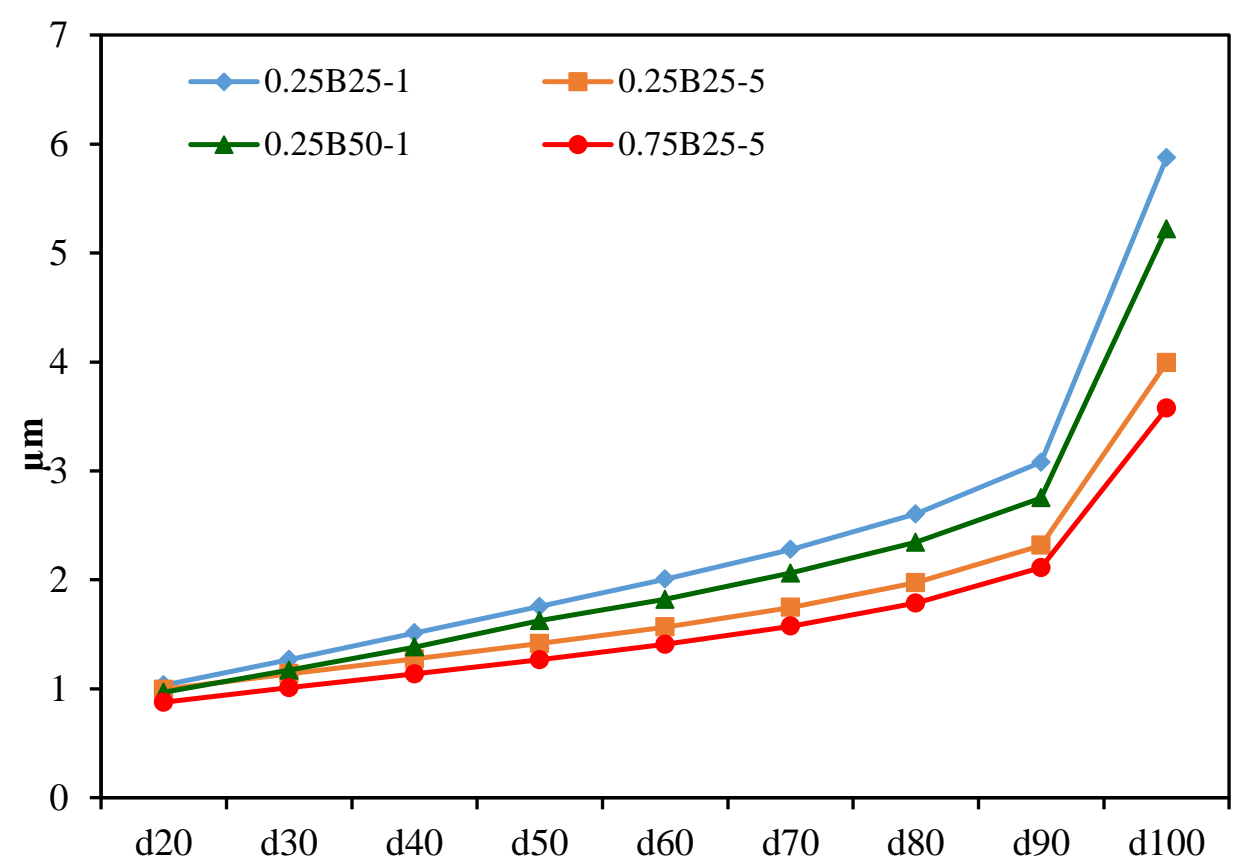

Şekil 3. PVS varlığında elde edilen $\mathrm{CaCO}_{3}$ kristalleri için sayısal boyut dă̆ılımı

Tablo 2. Elde edilen kalsiyum karbonat kristallerinin d50 değerleri

\begin{tabular}{ll|ll}
\hline Numune & $\mathrm{d} 50(\mu \mathrm{m})$ & Numune & $\mathrm{d} 50(\mu \mathrm{m})$ \\
\hline $0.25 \mathrm{~B} 25-1$ & 1.757 & $0.25 \mathrm{~B} 25-5$ & 1.415 \\
$0.25 \mathrm{~B} 50-1$ & 1.626 & $0.25 \mathrm{~B} 50-5$ & 1.435 \\
$0.75 \mathrm{~B} 25-1$ & 1.362 & $0.75 \mathrm{~B} 25-5$ & 1.267 \\
$0.75 \mathrm{~B} 50-1$ & 1.333 & $0.75 \mathrm{~B} 50-5$ & 1.229 \\
\hline
\end{tabular}

\subsection{TGA-DTA Analiz Sonuçları}

Termogravimetrik analiz oksijen atmosferinde dakikada $10{ }^{\circ} \mathrm{C}$ 'lik 1 sitma hızı ile numunelerin $800{ }^{\circ} \mathrm{C}$ 'ye 1sıtılmasıyla gerçekleştirilmiştir. Elde edilen kalsiyum karbonat kristallerin TGA-DTA analiz sonuçları Şekil 4'te verilmiştir. Numunelere ait sıcaklık ve kütle kaybı arasındaki ilişki ise Tablo 3'te verilmiştir.

TGA-DTA analizleri sonucunda numunelerde aşamalı kütle kaybı olduğu görülmektedir. $150{ }^{\circ} \mathrm{C}$ 'ye kadar olan kısımdaki kütle kaybı numuneden uzaklaşan nemi göstermektedir. PVS polimerinin bozunması 150 ${ }^{\circ} \mathrm{C}$ 'de başlar ve $300{ }^{\circ} \mathrm{C}$ 'ye kadar devam eder. Polimerin bozunmasını gösteren ekzotermik pik yaklaşık $300{ }^{\circ} \mathrm{C}$ civarında gözlenmiştir. Şekil 4 'ten görüleceği üzere polimer konsantrasyonunun yüksek olduğu numunede kütle kaybı bu sıcaklık aralığında daha yüksektir. Asıl kütle kaybı $600-800{ }^{\circ} \mathrm{C}$ arasında olmaktadır. Bu sıcaklık aralığında kalsiyum karbonat bozunup CaO’e dönüşmektedir [28]. 
Tablo3. Kalsiyum karbonat kristallerinin sıcaklıklara göre kütle kayıpları

\begin{tabular}{|c|c|c|c|}
\hline Ağırlık $(\%)$ & $0.75 \mathrm{~B} 25-5$ & $0.25 \mathrm{~B} 25-5$ & $0.25 \mathrm{~B} 25-1$ \\
\hline Sicaklık $\left({ }^{\circ} \mathrm{C}\right)$ & & & \\
\hline $0-300$ & 3.76 & 2.34 & 2.52 \\
\hline $300-600$ & 2.93 & 2.24 & 2.04 \\
\hline $600-800$ & 34.49 & 39.80 & 38.98 \\
\hline$\Sigma$ kütle kayb1 & 41.18 & 44.38 & 43.58 \\
\hline
\end{tabular}
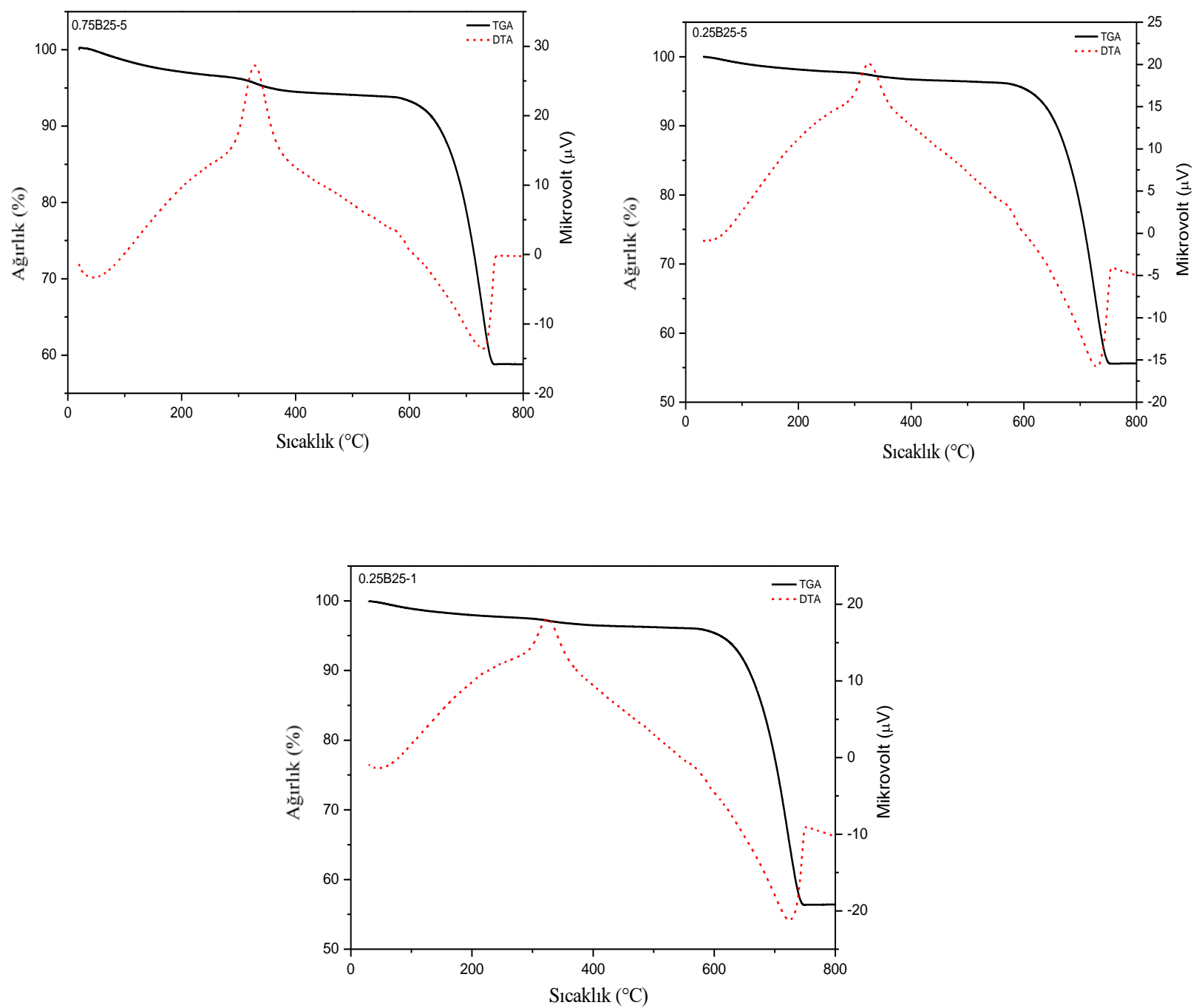

Şekil 4. Kalsiyum karbonat kristallerinin TGA-DTA ĕgrileri 


\subsection{Deney Tasarımı Tabanlı Modelleme}

USD ortamında geçekleştirilen kristalizasyon çalışmalarında parametrelerin etkileri tek değişkenli olarak incelenmesinin yanı sıra parametrelerin aynı anda değiştirilmesi ile meydana gelecek değişiklikleri belirlemek için deneysel tasarım yöntemi uygulanmıştır. Bu çalışmada, deneysel tasarım yöntemi olarak sıklıkla uygulanan $2^{\mathrm{k}}$ Faktöriyel Tasarım yöntemi seçilmiştir. Deneysel tasarım planı, ilgili çalışma aralığındaki parçacık boyutu dağılımını en doğru şekilde belirlemek amacı ile uygulanmıştır. Model denklik d50 değerleri için uygulanmıştır. Kristalizasyonda incelenmek üzere seçilen parametreler polimer konsantrasyonu, sonikatör genliği ve USD uygulama zamanı sırasıyla $\mathrm{x}_{1}, \mathrm{x}_{2}$ ve $\mathrm{x}_{3}$ şeklinde kodlanmıştır. $2^{\mathrm{k}}$ Faktöriyel Tasarım için kodlamalar çalışma aralıklarının en düşük değerinde -1 ve en yüksek değerinde +1 olacak şekilde yapılmıştır. $2^{\mathrm{k}}$ Faktöriyel Tasarım için çalışma aralıklarının en düşük ve en yüksek değerlerine göre belirlenen seviye değerleri Tablo 4 'te verilmiştir.

Tablo 4. Deneysel tasarım için incelenen faktörlerin seviye değerleri

\begin{tabular}{cccc}
\hline Seviye & $\mathrm{x}_{1}([\mathrm{PVS}], \mathrm{g} / \mathrm{L})$ & $\mathrm{x}_{2}($ Genlik, \%) & $\mathrm{x}_{3}$ (Zaman, dk) \\
\hline-1 & 0.25 & 25 & 1 \\
+1 & 0.75 & 50 & 5 \\
\hline
\end{tabular}

Eşitlik (2.1) yardımı ile deneylerden elde edilen değerleri kullanarak, model denkliğin katsayılarını veren regresyon analizi yapıldıktan sonra parçacık boyutu dağılımı $(\mathrm{Y})$ için geliştirilen model denklem Eşitlik (3.1) ile verilmektedir. Model denkliğin korelasyon katsayısı 0.99 olarak bulunmuştur. Korelasyon katsayısının 0.99 olması, sadece verilerin \%1'inin bu model denklikle açıklanamadığını göstermektedir [1]. Önerilen denklik ile ilgili varyans analizinin sonuçları Tablo 5’te verilmiştir.

$$
Y=1.43-0.13 x_{1}-0.02 x_{2}-0.09 x_{3}+0.04 x_{1} x_{3}-0.02 x_{1} x_{2} x_{3}
$$

Varyans analizi sonucunda parçacık boyutu modeli için hesaplanan $p$ değeri 0.03 olarak bulunmuştur. Bu değere göre, hesaplanan $p$ değeri 0.05 ten küçük olduğu için \%95 önem seviyesi şartını sağlamaktadır. Sağlanması istenen önem seviyesi \%95 olduğundan önerilen model denklik uygun olarak görülmüştür. Ayrıca deneysel değerler ile model denklikten elde edilen değerler arasındaki kalanlar toplamı 4.44E-16 olarak bulunmuştur. Korelasyon sayısının 1'e yakın olması ve kalanlar toplamının neredeyse 0 değerinde olması oluşturulan model denklemin uygunluğunu desteklemektedir.

Tablo 5.Deneysel Tasarımla elde edilen model denklemin ANOVA analiz sonucu

\begin{tabular}{lccccc}
\hline Kaynak & $d f$ & SS & MS & F & $p$ değeri \\
\hline Regresyon & 5 & 0.22 & 0.04 & 32.41 & 0.03 \\
Fark & 2 & 0.00 & 0.00 & & \\
Toplam & 7 & 0.23 & & & \\
\hline
\end{tabular}

$d f$ : Serbestlik Derecesi, SS: Karelerin Toplamı, MS:

Ortalama Kare, F: F oranı

Önerilen model denklik incelendiğinde ana faktöre bağlı katsayılar $\mathrm{x}_{1}, \mathrm{x}_{2}, \mathrm{x}_{3}$ için sırasıyla $-0.13,-0.02$ ve 0.09 olarak elde edilmiştir. Model denklikteki katsayıların pozitif ya da negatif olması faktörlerin cevap ile doğru ya da ters orantılı olduğunu göstermektedir. Ana faktörlere $\left(\mathrm{x}_{1}, \mathrm{x}_{2}, \mathrm{x}_{3}\right)$ ait katsayıların negatif değerde olması polimer konsantrasyonu, sonikatör genliği ve USD uygulama zamanının arttırılmasının parçacık boyutunda düşüşe neden olacağını göstermektedir. Model denklikte en büyük katsayı polimer 
konsantrasyonuna ( $\mathrm{x}_{1}$ için 0.13 ) ait olup, deneysel koşullarda en etkili parametrenin polimer konsantrasyonu olduğunu göstermektedir. Şekil 3 ve Tablo 2'de görüldüğü üzere parçacık boyutundaki en büyük değişim polimer konsantrasyonu değiştirildiğinde elde edilmiştir. Model denklikten elde edilen katsayıda bunu desteklemektedir. Polimer konsantrasyonunu sirasiyla USD uygulama zamanı ve sonikatör genliği takip etmektedir. Model denklikten sadece ana parametrelerin etkisi değil aynı zamanda parametrelerin birlikte değiştirilmesi ile meydana gelen etki de görülmektedir. Polimer konsantrasyonu $\left(\mathrm{x}_{1}\right)$ ve USD uygulama zamanının $\left(\mathrm{x}_{3}\right)$ etkisinin birlikte incelendiğini gösteren katsayı $\left(\mathrm{x}_{1} \mathrm{x}_{3}\right.$ için 0.04$)$ pozitif değerdedir. $\mathrm{Bu}$ da $\mathrm{x}_{1}$ ve $\mathrm{x}_{3}$ değerinin aynı anda artması ile parçacık boyutunun arttı̆̆ını ifade etmektedir. Parametrelerin üçlü etkisini gösteren $\mathrm{x}_{1} \mathrm{x}_{2} \mathrm{x}_{3}$ ifadesinin katsayısı negatiftir (-0.02). Bu durumda parametrelerin üçü de aynı anda arttığında parçacık boyutu azalmaktadır.

Deneysel değerler (Tablo 2) ile model denklikten elde edilen değerler arasındaki ilişki Şekil 5'te verilmiştir. Şekil 5 'ten görüleceği üzere deneysel değerler ile denklikten elde edilen değerler birbirine çok yakındır. Bu da önerdiğimiz model denkliğin uygunluğunu desteklemektedir.

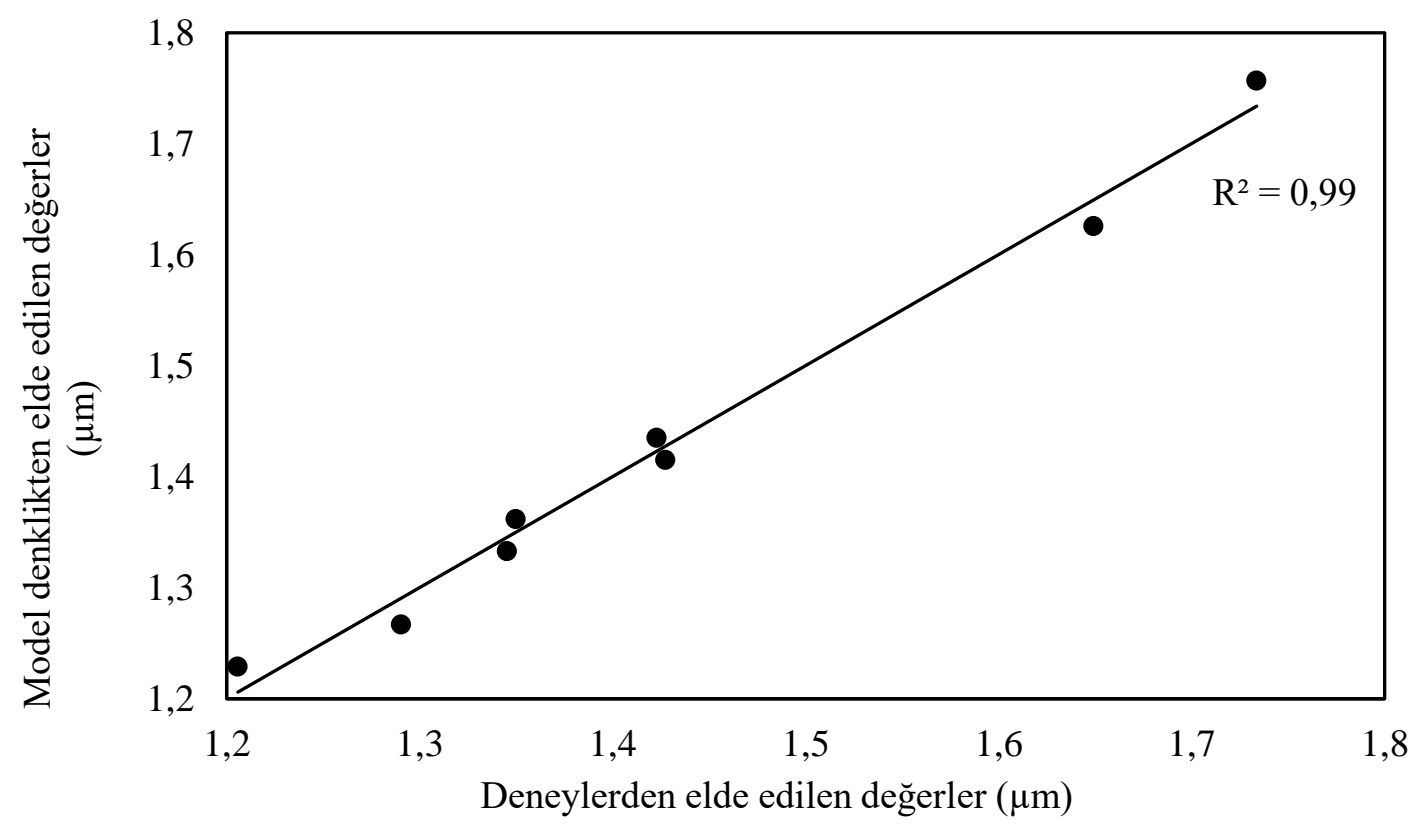

Şekil 5. Deneysel değerlere karşılık model denklikten elde edilen değerler arasındaki ilişki

\section{SONUÇ (CONCLUSION)}

Kalsiyum karbonat kristalizasyonu, PVS polimeri varlığında ultrasonik ses dalgası (USD) uygulanarak incelenmiştir. Kalsiyum karbonat kristallerinin kontrollü sentezinde; sonikatör genlik değeri, USD uygulama zamanı ve polimer konsantrasyonunun etkisi incelenmiştir.

PVS varlığında elde edilen numuneler küresel vaterit polimorfunu içermektedir. Polimer ilavesi ile kalsiyum karbonatın polimorfu değişmiştir. Vaterit polimorfunun PVS polimerinin yapıya girmesi ile kararlı hale geldiği XRD ve SEM görüntüleri ile desteklenmiştir.

Kalsiyum karbonat kristalizasyonunda incelenen parametrelerin çoklu etkileşimini görmek için çalışma aralığında deneysel tasarım uygulanmıştır. Deneysel koşullar $2^{\mathrm{k}}$ Faktöriyel Tasarıma göre belirlenip, parametrelerin parçacık boyutuna (d50) etkisi incelenmiştir. Model denkliğin uygunluğu korelasyon katsayısı, kalanların farkı ve $p$ değeri ile değerlendirilmiştir. Model denkliği için korelasyon katsayısı $0.99, p$ değeri 0.03 ve kalanlar toplamı 4.44E-16 olarak bulunmuştur. Korelasyon katsayısının 1'e yakın olması, kalanların toplamının 0'a yakın olması ve $p$ değerinin 0.05 'ten küçük olması model denkliğinin uygunluğunu desteklemiştir. 
Polimer varlığında, USD uygulaması ile elde edilen kristallerde, ortalama kristal boyutu polimer konsantrasyonundan çok etkilenmiştir. Ana faktörlere ait katsayılar negatif değerde elde edilmiştir. Bu da proses parametrelerinin artması ile parçacık boyutu azaldığını göstermiştir. Parametrelerin parçacık boyutuna etkisi polimer konsantrasyonu $\left(\mathrm{x}_{1}\right.$ için 0.13$)>$ USD uygulama zamanı $\left(\mathrm{x}_{3}\right.$ için 0.09$)>$ sonikatör genliği ( $\mathrm{x}_{2}$ için 0.02$)$ şeklinde olduğu görülmüştür. SEM ve parçacık boyut analizi ile sonuçlar desteklenmiştir.

$\mathrm{Bu}$ çalışmada, kalsiyum karbonat kristallerinin kontrollü sentezinde katkı maddesinin ve proses parametrelerinin kalsiyum karbonat kristal boyutu ve polimorf yapısında çok etkili olduğu gözlenmiştir. Kristal boyut ve polimorf endüstriyel uygulamalar için önemli parametrelerdir. Kalsiyum karbonat kristalizasyonunda proses parametreleri kontrol edilerek endüstriyel uygulamalar için spesifik ürün elde etmek mümkün olabilir.

\section{TEȘEKKÜR (ACKNOWLEDGMENTS)}

$\mathrm{Bu}$ araştırma Yıldız Teknik Üniversitesi Bilimsel Araştırma Projeleri Koordinatörlüğü'nce desteklenmiştir. Proje No:2013-07-01-GEP05.

\section{KAYNAKLAR (REFERENCES)}

[1] S. Kirboga, M. Oner, Application of experimental design for the precipitation of calcium carbonate in the presence of biopolymer. Powder Technology, 249 (2013) 95-104.

[2] S. Kirboga, M. Oner, Effect of the Experimental Parameters on Calcium Carbonate Precipitation. Icheap-11: 11th International Conference on Chemical and Process Engineering, Pts 1-4 32, (2013) 2119-2124.

[3] S. Kirboga, M. Oner, Investigation of calcium carbonate precipitation in the presence of carboxymethyl inulin. Crystengcomm, 15 (2013) 3678-3686.

[4] S. Kirboga, M. Oner, E. Akyol, The effect of ultrasonication on calcium carbonate crystallization in the presence of biopolymer. Journal of Crystal Growth, 401 (2014) 266-270.

[5] L. Zhao, Y. Zhang, Y. Miao, L. Nie, Controlled synthesis, characterization and application of hydrophobic calcium carbonate nanoparticles in PVC. Powder Technology, 288 (2016) 184-190.

[6] Z. Amjad, Precipitation of calcium carbonate in aqueous systems. Tenside Surfactants Detergents, 36 (1999) 162-167.

[7] S. H. Sonawane, S. P. Gumfekar, S. Meshram, M. P. Deosarkar, C. M. Mahajan, P. Khanna, Combined Effect of Surfactant and Ultrasound on Nano Calcium Carbonate Synthesized by Crystallization Process. International Journal of Chemical Reactor Engineering, 7, (2009).

[8] G. J. Price, M. F. Mahon, J. Shannon, C. Cooper, Composition of Calcium Carbonate Polymorphs Precipitated Using Ultrasound. Crystal Growth \& Design, 11 (2011) 39-44.

[9] E. Dalas, The effect of ultrasonic field on calcium carbonate scale formation. Journal of Crystal Growth, 222 (20001) 287-292.

[10] C. D. Mateescu, M. Mocioi, C. Sarbu, R. Isopescu, I. Chilibon, F. Branzoi, Calcium carbonate precipitation in ultrasonic field., 13th International Workshop on Industrial Crystallization, (2006) 193-200. 
[11] I. Nishida, I. Precipitation of calcium carbonate by ultrasonic irradiation. Ultrasonics Sonochemistry, 11 (2004) 423-428.

[12] R. M. Wagterveld, H. Miedema, G.-J. Witkamp, Effect of Ultrasonic Treatment on Early Growth during CaCO3 Precipitation. Crystal Growth \& Design, 12 (2012) 4403-4410.

[13] A. Stoica-Guzun, M. Stroescu, S. Jinga, I. Jipa, T. Dobre, L. Dobre, Ultrasound influence upon calcium carbonate precipitation on bacterial cellulose membranes. Ultrasonics Sonochemistry, 19 (2012) 909-915.

[14] Y. Mori, T. Enomae, A. Isogai, Preparation of vaterite type calcium carbonate by using ultrasound and application to ink-jet paper. 24th Internationational Conference on Digital Printing Technologies/Digital Fabrication, (2008) 761-764.

[15] Y. Kojima, M. Kanai, N. Nishimiya, Synthesis of novel amorphous calcium carbonate by sono atomization for reactive mixing., Ultrasonics Sonochemistry, 19 (2012) 325-329.

[16] S. Kirboga, M. Oner, The role of vinyl sulfonic acid homopolymer in calcium oxalate crystallization. Colloids and Surfaces B-Biointerfaces, 78 (2010) 357-362.

[17] G.C.S. Wang, C. L. Jain, Regression Analysis: Modeling and Forecating. New York: Graceway Publishing Company Inc., 2003.

[18] P. Malkaj, E. Dalas, Effect of metallocene dichlorides on the crystal growth of calcium carbonate. Journal of Crystal Growth, 242 (2002) 405-411.

[19] J. Garcia-Carmona, J. G. Morales, R. Rodriguez-Clemente, Morphological control of precipitated calcite obtained by adjusting the electrical conductivity in the $\mathrm{Ca}(\mathrm{OH})(2)-\mathrm{H} 2 \mathrm{O}-\mathrm{CO} 2$ system. Journal of Crystal Growth, 249 (2003) 561-571.

[20] E. Akyol, K. Ongun, S. Kirboga, M. Oner, M., A kinetic study for calcium oxalate crystallization in the presence of Viburnum opulus extract. Biointerface Research in Applied Chemistry, 6 (2016) 1064-1069.

[21] E. Dalas, P. G. Klepetsanis, P.G. Koutsoukos, Calcium carbonate deposition on cellulose. Journal of Colloid and Interface Science, 224 (2000) 56-62.

[22] Y. H. Shen, A. J. Xie, Z. X. Chen, W. H. Xu, H. Yao, S. K. Li, L. C. Huang, Z. F. Wu, X. Y. Kong, Controlled synthesis of calcium carbonate nanocrystals with multi-morphologies in different bicontinuous microemulsions. Materials Science and Engineering a-Structural Materials Properties Microstructure and Processing, 443 (2007) 95-100.

[23] A. Szczes, Influence of the surfactant nature on the calcium carbonate synthesis in water-in-oil emulsion. Journal of Crystal Growth, 311 (2009) 1129-1135.

[24] J. Kanakis, E. Dalas, The crystallization of vaterite on fibrin. Journal of Crystal Growth, 219 (2000) 277-282.

[25] F. Manoli, E. Dalas, Calcium carbonate crystallization in the presence of glutamic acid. Journal of Crystal Growth, 222 (2001) 293-297.

[26] A. T. Nagaraja, S. Pradhan, M. J. McShane, Poly (vinylsulfonic acid) assisted synthesis of aqueous solution stable vaterite calcium carbonate nanoparticles. Journal of Colloid and Interface Science, 418 (2014) 366-372.

[27] L. Jonkers, M. A. Prins, G.-J.A. Brummer, M. Konert, B. C. Lougheed, Experimental insights into laser diffraction particle sizing of fine-grained sediments for use in palaeoceanography. Sedimentology, 56 (2009) 2192-2206. 
[28] S. Kirboga, M. Oner, The inhibitory effects of carboxymethyl inulin on the seeded growth of calcium carbonate. Colloids and Surfaces B-Biointerfaces, 91 (2012) 18-25. 